\title{
Two New Triterpenoids from Lysimachia heterogenea Klatt and Evaluation of Their Cytotoxicity
}

\author{
Xin-An Huang ${ }^{1}$, Xiao-Ling Shen ${ }^{1}$, Ying-Jie Hu ${ }^{1}$, Ya-Ming Liu ${ }^{2}$, Kang-Lun Liu ${ }^{1}$, \\ Feng-Xue Zhang ${ }^{1, *}$ and Xin-Xin Zhou ${ }^{3, *}$
}

1 Tropical Medicine Institute, Guangzhou University of Chinese Medicine, Guangzhou 510405, China; E-Mails: xahuang@163.net (X.-A.H.); xlshen66@hotmail.com (X.-L.S.); yjhu01@126.com (Y.-J.H.); LSDXLL@163.com (K.-L.L.)

2 The First Affiliated Hospital, Guangzhou University of Chinese Medicine, Guangzhou 510405, China; E-Mail: yaminliu@yahoo.com

3 College of Vocational and Technical Education, Guangzhou University of Chinese Medicine, Guangzhou 510405, China

* Authors to whom correspondence should be addressed; E-Mails: doczhang@tom.com (F.-X.Z.); xinxin_zhou@163.com (X.-X.Z.); Fax: +86-20-8637-3516 (F.-X.Z.) or +86-20-8638-2916 (X.-X.Z.).

Received: 15 August 2011; in revised form: 7 September 2011 / Accepted: 8 September 2011 / Published: 20 September 2011

\begin{abstract}
Two new 13,28-epoxy oleanane-type triterpenoids, namely heterogenoside E and $\mathrm{F}$, were isolated from Lysimachia heterogenea Klatt, together with the eight known compounds: palmitic acid, $\beta$-stigmasterol, kaempferol, quercetin, hyperin, isorhamnetin, isorhamnetin-3-O-galactopyranoside and anagallisin $\mathrm{C}$. Heterogenoside $\mathrm{F}$ possesses acetoxyl groups at the unusual $\mathrm{C}-21$ and $\mathrm{C}-22$ positions of its oleanane skeleton. The cytotoxic activities of anagallisin $\mathrm{C}$, heterogenoside $\mathrm{E}$ and $\mathrm{F}$ were weak.
\end{abstract}

Keywords: Lysimachia heterogenea Klatt; triterpenoids; cytotoxicity

\section{Introduction}

In a previous cytotoxicity-guided phytochemical screening, we found four 12-oleanene derivatives in the cytotoxic fractions of Lysimachia heterogenea Klatt [1]. L. heterogenea Klatt belongs to the genus Lysimachia, which is rich in triterpenoids [2]. As a continuation of our exploration of the 
ingredients in other fractions of this species, we report in this paper the isolation and structural identification of two new 13,28-epoxy oleanane-type triterpenoids, heterogenoside E (8) and F (9), isolated together with eight known compounds [palmitic acid (1), $\beta$-stigmasterol (2), isorhamnetin (3), kaempferol (4), quercetin (5), isorhamnetin-3-O-galactopyranoside (6), hyperin (7) and anagallisin $\mathrm{C}$ (10)]. The cytotoxic activities of compounds $\mathbf{8 , 9}$ and $\mathbf{1 0}$ were also evaluated.

\section{Results and Discussion}

\subsection{Structure Elucidation of New Compounds}

Heterogenoside $E(\mathbf{8})$, obtained as white powder $(\mathrm{MeOH})$, had the molecular formula of $\mathrm{C}_{46} \mathrm{H}_{74} \mathrm{O}_{17}$ according to its HRESIMS data. The degrees of molecular unsaturation were calculated to be 10 , among which three sugar rings, deduced from the reaction products of the chemical analysis and three pairs of anomeric protons and carbons in ${ }^{1} \mathrm{H}$ - and ${ }^{13} \mathrm{C}$-NMR spectra (Table 1), accounted for three degrees, and the $\mathrm{C}=\mathrm{O}$ group inferred from the $\delta 212.0$ peak in the ${ }^{13} \mathrm{C}-\mathrm{NMR}$ spectrum was another one.

Table 1. ${ }^{1} \mathrm{H}$ - and ${ }^{13} \mathrm{C}-\mathrm{NMR}$ data for the sugar moieties of compounds 8 and 9.

\begin{tabular}{|c|c|c|c|c|}
\hline \multirow{2}{*}{ No. } & \multicolumn{2}{|r|}{ Compound 8} & \multicolumn{2}{|r|}{ Compound 9} \\
\hline & $\mathrm{C}$ & $\mathrm{H}$ & $\mathrm{C}$ & $\mathrm{H}$ \\
\hline \multicolumn{5}{|c|}{ arabinose' } \\
\hline 1 & 106.5 & $4.87(d, 7.5 \mathrm{~Hz})$ & 104.6 & $4.78(d, 6.0 \mathrm{~Hz})$ \\
\hline 2 & 81.1 & $4.08(b r s)$ & 79.7 & $4.57^{\mathrm{a}}$ \\
\hline 3 & 73.9 & $4.25^{\mathrm{a}}$ & 73.2 & $4.30^{\mathrm{a}}$ \\
\hline 4 & 74.5 & $4.31^{\mathrm{a}}$ & 78.4 & $4.31^{\mathrm{a}}$ \\
\hline 5 & 66.5 & $3.65(d, 12.5 \mathrm{~Hz}), 4.60(d, 12.5 \mathrm{~Hz})$ & 64.1 & $3.68(m), 4.65(d d, 12.0 \mathrm{~Hz}, 4 \mathrm{~Hz})$ \\
\hline \multicolumn{5}{|c|}{ glucose" (at C-2 of arabinose) } \\
\hline 1 & 105.3 & $5.01(d, 7.5 \mathrm{~Hz})$ & 104.9 & $5.50(d, 7.5 \mathrm{~Hz})$ \\
\hline 2 & 86.2 & $3.95^{\mathrm{a}}$ & 76.0 & $3.70-4.20^{\mathrm{a}}$ \\
\hline 3 & 77.9 & $3.80-4.30^{\mathrm{a}}$ & 77.8 & $3.80-4.30^{\mathrm{a}}$ \\
\hline 4 & 71.0 & $4.25^{\mathrm{a}}$ & 71.9 & $4.25^{\mathrm{a}}$ \\
\hline 5 & 78.2 & $3.80-4.30^{\mathrm{a}}$ & 78.2 & $3.80-4.30^{\mathrm{a}}$ \\
\hline 6 & 62.4 & $4.32(\mathrm{~m}), 4.45(\mathrm{~m})$ & 63.0 & $4.60(m)$ \\
\hline \multicolumn{5}{|c|}{ glucose"' (at C-4 of arabinose) } \\
\hline 1 & & & 104.1 & $5.02(d, 7.5 \mathrm{~Hz})$ \\
\hline 2 & & & 85.4 & $3.91(\mathrm{~m})$ \\
\hline 3 & & & 77.6 & $3.80-4.30^{\mathrm{a}}$ \\
\hline 4 & & & 71.1 & $4.21^{\mathrm{a}}$ \\
\hline 5 & & & 77.9 & $3.80-4.30^{\mathrm{a}}$ \\
\hline 6 & & & 62.4 & $4.32^{\mathrm{a}}$ \\
\hline \multicolumn{5}{|c|}{ xylose (xylose"' for $\mathbf{8}$ and xylose"'" for $\mathbf{9}$ ) } \\
\hline 1 & 108.0 & $4.89(d, 6.5 \mathrm{~Hz})$ & 107.6 & $4.93(d, 6.0 \mathrm{~Hz})$ \\
\hline 2 & 76.2 & $3.80-4.30^{\mathrm{a}}$ & 76.2 & $3.70-4.20^{\mathrm{a}}$ \\
\hline 3 & 77.6 & $3.80-4.30^{\mathrm{a}}$ & 78.3 & $3.80-4.30^{\mathrm{a}}$ \\
\hline 4 & 70.4 & $3.80-4.30^{\mathrm{a}}$ & 70.7 & $4.15^{\mathrm{a}}$ \\
\hline 5 & 67.2 & $3.48(m), 4.28^{\mathrm{a}}$ & 67.4 & $3.72(m), 4.56^{\mathrm{a}}$ \\
\hline
\end{tabular}

${ }^{\mathrm{a}}$ The signals were overlapped. 
The remaining six degrees, six distinct quaternary methyl groups, and the saturated carbons in high field of the ${ }^{13} \mathrm{C}$-NMR spectrum all implied the existence of a saponin aglycon (Table 2).

Table 2. The main ${ }^{1} \mathrm{H}$ and ${ }^{13} \mathrm{C}$-NMR data for the aglycon moieties of compounds 8 and 9 $\left(125 \mathrm{MHz}\right.$ in pyridine- $\left.d_{5}\right)$.

\begin{tabular}{|c|c|c|c|c|}
\hline \multirow{2}{*}{ No. } & \multicolumn{2}{|r|}{ Compound 8} & \multicolumn{2}{|r|}{ Compound 9} \\
\hline & $\mathrm{C}$ & $\mathrm{H}$ & $\mathrm{C}$ & $\mathrm{H}$ \\
\hline 1 & 39.1 & $1.02^{\mathrm{a}}, 1.72(\mathrm{~m})$ & 39.2 & $0.85^{\mathrm{a}}, 1.63(\mathrm{~m})$ \\
\hline 2 & 26.1 & $2.02(\mathrm{~m}), 2.23(\mathrm{~m})$ & 26.5 & $1.90(\mathrm{~m})$ \\
\hline 3 & 81.9 & $4.24^{\mathrm{a}}$ & 88.9 & $3.12(d d, 11.5 \mathrm{~Hz}, 4.0 \mathrm{~Hz})$ \\
\hline 4 & 43.6 & & 39.7 & \\
\hline 5 & 47.4 & $1.58(m)$ & 55.6 & $0.63(d, 11.5 \mathrm{~Hz})$ \\
\hline 6 & 17.5 & $1.66(\mathrm{~m})$ & 17.8 & $1.40^{\mathrm{a}}$ \\
\hline 7 & 33.6 & $1.04^{\mathrm{a}}, 1.47^{\mathrm{a}}$ & 34.2 & $1.32^{\mathrm{a}}$ \\
\hline 8 & 43.0 & & 42.6 & \\
\hline 9 & 50.3 & $1.28(\mathrm{~m})$ & 50.4 & $1.23^{\mathrm{a}}$ \\
\hline 10 & 36.7 & & 36.8 & \\
\hline 11 & 18.9 & $1.26^{\mathrm{a}}, 1.51^{\mathrm{a}}$ & 19.1 & $1.26-1.51^{\mathrm{a}}$ \\
\hline 12 & 31.7 & $1.52(\mathrm{~m})$ & 32.6 & $1.52(m)$ \\
\hline 13 & 86.2 & & 86.0 & \\
\hline 14 & 49.8 & & 44.7 & \\
\hline 15 & 45.8 & $1.91(d, 15 \mathrm{~Hz}), 2.82(d, 15 \mathrm{~Hz})$ & 32.8 & $1.45(m)$ \\
\hline 16 & 212.0 & & 78.4 & $3.80-4.30^{\text {a }}$ \\
\hline 17 & 56.1 & & 50.9 & \\
\hline 18 & 54.6 & $2.01(\mathrm{~m})$ & 49.4 & $1.85(\mathrm{~m})$ \\
\hline 19 & 40.0 & $1.40(\mathrm{~m})$ & 38.3 & $1.46^{\mathrm{a}}, 2.64(t, 15.0 \mathrm{~Hz})$ \\
\hline 20 & 31.8 & & 37.1 & \\
\hline 21 & 35.6 & $1.19(\mathrm{~m}), 1.79(\mathrm{~m})$ & 80.4 & $5.80(d, 10.0 \mathrm{~Hz})$ \\
\hline 22 & 25.0 & $2.24^{\mathrm{a}}$ & 74.3 & $4.30^{\mathrm{a}}$ \\
\hline 23 & 64.3 & $3.69^{\mathrm{a}}, 4.33^{\mathrm{a}}$ & 28.0 & $1.23^{\mathrm{a}}$ \\
\hline 24 & 13.3 & $0.96(s)$ & 16.6 & $1.08(s)$ \\
\hline 25 & 16.7 & $0.94(s)$ & 16.3 & $0.81(s)$ \\
\hline 26 & 18.8 & $1.32(s)$ & 18.3 & $1.25^{\mathrm{a}}$ \\
\hline 27 & 21.7 & $1.01(s)$ & 19.8 & $1.27^{\mathrm{a}}$ \\
\hline 28 & 75.1 & $3.50(m)$ & 76.2 & $4.10^{\mathrm{a}}$ \\
\hline 29 & 33.3 & $0.86(s)$ & 30.3 & $1.13(s)$ \\
\hline 30 & 23.5 & $0.81(s)$ & 20.2 & $1.10(s)$ \\
\hline \multicolumn{5}{|c|}{$\mathrm{AcO}$ (at C-21 of aglycon) } \\
\hline $\mathrm{CO}$ & & & 171.1 & \\
\hline $\mathrm{Me}$ & & & 21.0 & 2.00 \\
\hline \multicolumn{5}{|c|}{$\mathrm{AcO}$ (at C-22 of aglycon) } \\
\hline $\mathrm{CO}$ & & & 169.7 & \\
\hline $\mathrm{Me}$ & & & 21.9 & 2.40 \\
\hline
\end{tabular}

${ }^{a}$ The signals were overlapped. 
The HMBC correlations from $\mathrm{H}-24$ to $\mathrm{C}-3, \mathrm{C}-4, \mathrm{C}-5$ and $\mathrm{C}-23$; $\mathrm{H}-25$ to $\mathrm{C}-1, \mathrm{C}-9$ and $\mathrm{C}-10$; $\mathrm{H}-26$ to C-7, C-8 and C-14; H-27 to C-8 and C-14; H-29 to C-19, C-20, C-21 and C-30; H-30 to C-20, C-21 and $\mathrm{C}-29$; and $\mathrm{H}-18$ to $\mathrm{C}-13$; as well as the consistency of carbon signals with those reported in [3], confirmed the aglycon to be anagalligenone. The carbon chemical shifts of the sugar moieties were identical to those of heterogenoside $\mathrm{B}$ as reported in reference [1], and the HMBC correlations from $\mathrm{H}^{\prime}-1$ to $\mathrm{C}-3, \mathrm{H}$ "-1 to $\mathrm{C}^{\prime}-2$ and $\mathrm{H}^{\prime \prime}-1$ to $\mathrm{C}^{\prime \prime}-2$, and the coupling constants of the anomeric protons at $\delta 4.87(J=7.5 \mathrm{~Hz}), 5.01(J=7.5 \mathrm{~Hz})$ and $4.89(J=6.5 \mathrm{~Hz})$ determined the glycosyl linkage as 3 - $O$ - $\{\beta$ - $D$-xylopyranosyl- $(1 \rightarrow 2)-\beta$ - $D$-glucopyranosyl- $(1 \rightarrow 2)-\alpha$ - $L$-arabinopyranosyl $\}$. Therefore, it was concluded that 8 was anagalligenone $3-O$ - $\{\beta$ - $D$-xylopyranosyl- $(1 \rightarrow 2)-\beta$ - $D$-glucopyranosyl- $(1 \rightarrow 2)$ $\alpha$-L-arabinopyranosyl\} (Figure 1).

Figure 1. The structures and key correlations for compounds 8 and 9.

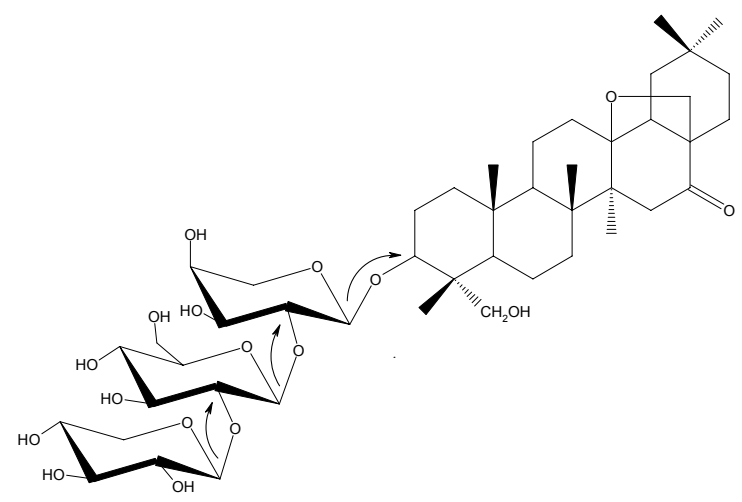

8

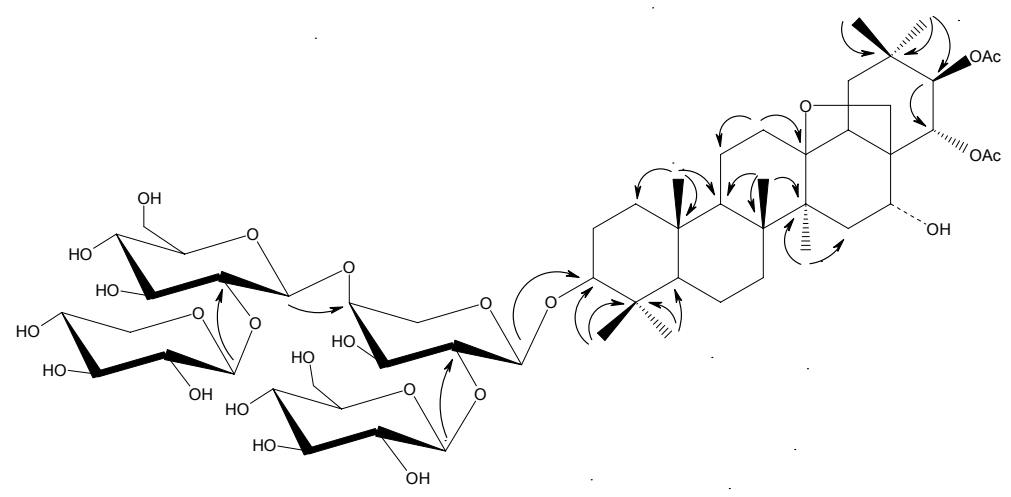

9

Heterogenoside $F(\mathbf{9})$, white powder $(\mathrm{MeOH})$, had the formula $\mathrm{C}_{56} \mathrm{H}_{90} \mathrm{O}_{25}$ according to its HRESIMS data, and the DEPT and HMBC spectra revealed two AcO groups (Table 2). Four pairs of anomeric protons and carbons in ${ }^{1} \mathrm{H}$ - and ${ }^{13} \mathrm{C}$-NMR spectra (Table 1), the carbon profile similar to that of heterogenoside $\mathrm{D}$, the coupling constants of the anomeric protons at $\delta 4.78(J=6.0 \mathrm{~Hz}), 5.50$ $(J=7.5 \mathrm{~Hz}), 5.02(J=7.5 \mathrm{~Hz})$ and $4.93(J=6.0 \mathrm{~Hz})$, and the HMBC correlations from $\mathrm{H}^{\prime \prime}-1$ to $\mathrm{C}^{\prime}-2$, $\mathrm{H}^{\prime \prime}-1$ to $\mathrm{C}^{\prime}-4, \mathrm{H}^{\prime \prime \prime}-1$ to $\mathrm{C}^{\prime \prime}-2$ supported the existence of a $\beta$-D-xylopyranosyl- $(1 \rightarrow 2)-\beta-D-$ glucopyranosyl-( $(1 \rightarrow 4)$-[ $\beta$ - $D$-glucopyranosyl- $(1 \rightarrow 2)]-\alpha$ - $L$-arabinopyranosyl moiety. The remaining eight degrees of unsaturation were assigned to the $\mathrm{AcO}$ moieties and a six-ring triterpenoid aglycon. HMBC correlations from $\mathrm{H}-21$ to carbon at $\delta 171.1$ and C-22; H-23 to C-3, C-4, C-5, C-24; H-24 to C-3, C-4, C-5 and C-23; H-25 to C-1, C-5, C-9 and C-10; H-26 to C-7, C-8, C-9 and C-14; H-27 to 
C-8, C-13, C-14 and C-15; H-29 to C-19, C-20, C-21 and C-30; H-30 to C-20, C-21 and C-29; led to the construction of 13,28-epoxy-3,16,21,22-tetrol oleanane. Extensive analysis of the correlation of H-29 and H-21 in the NOESY spectrum, the coupling constant of H-21 $(J=10.0 \mathrm{~Hz})$ and the referenced structures in the literature [4,5] implied the $\alpha$ and $\beta$ configuration of $\mathrm{H}-21$ and $\mathrm{H}-22$, respectively. The HMBC correlation from H'-1 to C-3 indicated that C-3 was linked to the glycon, thus, 9 was finally

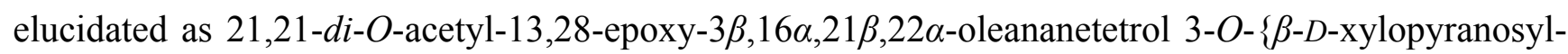
$(1 \rightarrow 2)$ - $\beta$ - $D$-glucopyranosyl- $(1 \rightarrow 4)$-[ $\beta$ - $D$-glucopyranosyl- $(1 \rightarrow 2)]-\alpha$ - $L$-arabinopyranosyl $\}$ (Figure 1$)$.

The structures of the other isolated components palmitic acid (1), $\beta$-stigmasterol (2), isorhamnetin (3), kaempferol (4), quercetin (5), isorhamnetin-3-O-galactopyranoside (6), hyperin (7) and anagallisin C (10) were determined by comparison to the ${ }^{1} \mathrm{H}$ and ${ }^{13} \mathrm{C}-\mathrm{NMR}$ spectral data in the literature [6-10].

\subsection{The Cytotoxic Activity of Anagallisin C, Heterogenoside E and F}

The biological assay results showed that the $\mathrm{IC}_{50}$ values of anagallisin $\mathrm{C}$ against the Hela, KB-3-1 and $\mathrm{HepG}_{2}$ cells were $35.7 \pm 6.0,30.7 \pm 2.9$ and $54.4 \pm 5.4 \mu \mathrm{M}$, while the corresponding values of heterogenoside E were $31.4 \pm 3.9,34.0 \pm 3.9$ and $31.7 \pm 4.9 \mu \mathrm{M}$, and those of heterogenoside $\mathrm{F}$ were $12.7 \pm 1.2,23.2 \pm 9.6$ and $21.0 \pm 3.7 \mu \mathrm{M}$, respectively.

\section{Experimental}

\subsection{General}

The experimental instruments for structural identification, the collection of the plant Lysimachia heterogenea Klatt, the preparation of fractions by liquid partition and column chromatography, and the methods of chemical analysis were as previously described $[1,11]$.

\subsection{Extraction and Isolation}

The petroleum ether, EtOAc and LH-2 fractions from L. heterogenea were collected as previously described [1], and every fraction was further chromatographed. The petroleum ether fraction $(30 \mathrm{~g})$ was subjected to silica gel column eluting with petroleum ether-acetone $(95: 5$ and $85: 15, \mathrm{v} / \mathrm{v})$ to give compounds 1 (200 mg) and 2 (500 mg). The EtOAc fraction (40 g) was chromatographed over silica gel with $\mathrm{MeOH}-\mathrm{CHCl}_{3}(10: 90$ and 20:80, v/v) to afford compounds 3 (40 mg), 4 (12 mg), 5 (60 mg), $6(9 \mathrm{mg})$, and 7 (7 mg). The LH-2 (20 g) fraction was further purified by silica gel chromatography with $\mathrm{MeOH}-\mathrm{CHCl}_{3}(20: 80$ and 25:75, v/v) to yield compounds 8 (20 mg), 9 (15 mg), and 10 (8 mg).

\subsection{Compound Characterization}

Heterogenoside E (8): $\mathrm{mp} 232-234{ }^{\circ} \mathrm{C} ;[\alpha]_{D}^{20}-20.0$ (c 0.25, MeOH); IR (KBr); v 3392, 1076 and 1044 $(\mathrm{OH}), 2946\left(\mathrm{CH}_{3}\right), 2924\left(\mathrm{CH}_{2}\right)$, and 1704 (16-ketone) $\mathrm{cm}^{-1} ;{ }^{1} \mathrm{H}$ - and ${ }^{13} \mathrm{C}-\mathrm{NMR}$ spectral data were listed in Tables 1 and 2; HRESIMS $m / z$ : $897.4853[\mathrm{M}-\mathrm{H}]^{-}$(calcd 897.4848).

Heterogenoside F (9): $\mathrm{mp} 216-217^{\circ} \mathrm{C}$; $[\alpha]_{D}^{20}-24.9$ (c 0.28, MeOH); IR (KBr); v 3396, 1077 and 1043 $(\mathrm{OH}), 2922$ (br. $\mathrm{CH}_{3}, \mathrm{CH}_{2}$ ), and 1721 (ester) $\mathrm{cm}^{-1} ;{ }^{1} \mathrm{H}$ - and ${ }^{13} \mathrm{C}-\mathrm{NMR}$ spectral data were listed in Tables 1 and 2; HRESIMS m/z: 1161.5701 [M-H] $^{-}$(calcd 1161.5693). 


\subsection{Cytotoxicity Bioassays}

The human epidermoid carcinoma cell line KB-3-1, human hepatocellular liver carcinoma cell line $\mathrm{HepG}_{2}$, and human epithelial carcinoma cell line Hela cells $\left(5 \times 10^{3}\right.$ cells/well) were cultured in 96well plates for $24 \mathrm{~h}$, respectively, then a buffer solution $(100 \mu \mathrm{L})$ containing the test compounds at various concentrations $(100,25,6.25,1.25 \mu \mathrm{g} / \mathrm{mL})$ was added to each well. The cells, treated with those compounds and DMSO (as the control), were incubated for $72 \mathrm{~h}$ at $37{ }^{\circ} \mathrm{C}$ in a humidified chamber. The culture was terminated by adding MTT solution $(20 \mu \mathrm{L}, 5 \mathrm{mg} / \mathrm{mL})$ to each well, and a further incubation for $4 \mathrm{~h}$ was performed. After the suspension was removed from each well, DMSO $(100 \mu \mathrm{L})$ was added and mixed thoroughly. The absorbance was measured by a microplate reader at $492 \mathrm{~nm}$ with $620 \mathrm{~nm}$ as reference, and mean $\mathrm{IC}_{50}$ values were calculated.

\section{Conclusions}

Eight known compounds (palmitic acid, $\beta$-stigmasterol, kaempferol, quercetin, hyperin, isorhamnetin, isorhamnetin-3-O-galactopyranoside and anagallisin $\mathrm{C}$ ), as well as two new triterpenoids, named heterogenoside $\mathrm{E}$ and $\mathrm{F}$, were isolated from Lysimachia heterogenea Klatt. Heterogenoside $\mathrm{F}$ is a rare 21,22-diacetoxyl triterpenoid. The cytotoxic activities of anagallisin $\mathrm{C}$, heterogenoside $\mathrm{E}$ and $\mathrm{F}$ were weak.

\section{Acknowledgments}

This program was partially supported by "211 Project” of Guangzhou University of Chinese Medicine.

\section{Conflict of Interest}

The authors declare no conflict of interest.

\section{References}

1. Huang, X.A.; Liang, Y.J.; Cai, X.L.; Feng, X.Q.; Zhang, C.H.; Fu, L.W.; Deng, W.D. Four new cytotoxic oligosaccharidic derivatives of 12-oleanene from Lysimachia heterogenea Klatt. Bioorg. Med. Chem. Lett. 2009, 19, 6515-6518.

2. Huang, X.A.; Yang, R.Z. Progress in the triterpenoids from the genus Lysimachia L. J. Trop. Subtrop. Bot. 2007, 15, 175-182.

3. Mahato, S.B.; Sahu, N.P.; Roy, S.K.; Sen, S. Structure elucidation of four new triterpenoid oligoglycosides from Anagallis arvensis. Tetrahedron 1991, 47, 5215-5230.

4. Liu, H.W.; Zhang, X.; Gao, H.; Wang, N.L.; Jin, S.L.; Cai, B.; Yao, X.S.; Cai, G.P. Two new triterpenoid glycosides isolated from Aesculus assamica Griff. Chem. Pharm. Bull. 2005, 53, 1310-1313.

5. Cao, S.G.; Norris, A.; Miller, J.S.; Ratovoson, F.; Razafitsalama, J.; Andriantsiferana, R.; Rasamison, V.E.; Kingston, D.G.I. Cytotoxic triterpenoid saponins of Albizia gummifera from the Madagascar rain forest. J. Nat. Prod. 2007, 70, 361-366. 
6. Huang, X.A.; Yang, R.Z. A new hydroquinone diglucoside from Lysimachia fordiana. Chem. Nat. Compd. 2004, 40, 457-459.

7. Huang, X.A.; Cai, J.Z.; Hu, Y.J.; Zhang, Y.H. Phytochemical investigation on Lysimachia fortunei. Chin. J. Chin. Mater. Med. 2007, 32, 596-599.

8. Salah, H.B.; Jarraya, R.; Martin, M.T.; Veitch, N.C.; Grayer, R.J.; Simmonds, M.S.J.; Damak, M. Flavonol triglycosides from the leaves of Hammada scoparia (Pomel) Iljin. Chem. Pharm. Bull. 2002, 50, 1268-1270.

9. Sukawa, K.; Sekine, H.; Takido, M. Two flavonol glycosides from Lysimachia fortunei. Phytochemistry 1989, 28, 2215-2216.

10. Wei, Y.; Xie, Q.Q.; Ito, Y. Preparative separation of axifolin-3-glucoside, hyperoside and amygdalin from plant extracts by high-speed countercurrent chromatography. J. Liq. Chromatogr. Relat. Technol. 2009, 32, 1010-1022.

11. Huang, X.A.; Yang, R.Z.; Deng, W.D. A new poly-substituted benzaldehyde from the leaves of Lysimachia fordiana Oliv. Molecules 2007, 12, 43-48.

Sample Availability: Samples of the compounds are available from the authors.

(C) 2011 by the authors; licensee MDPI, Basel, Switzerland. This article is an open access article distributed under the terms and conditions of the Creative Commons Attribution license (http://creativecommons.org/licenses/by/3.0/). 